\title{
Contamination of corn grain for human consumption with transgenic sequences in Paraguay
}

\author{
María Elena DAMÚS MELGAREJO ${ }^{1}$, Pastor Enmanuel PÉREZ ESTIGARRIBIA², Julio MASARU IEHISA, \\ Juliana Moura Mendes ARRUA ${ }^{4}$, Cinthia Carolina CAZAL MARTÍNEZ ${ }^{5}$, Andrea Alejandra ARRUA ${ }^{4 *}$
}

\begin{abstract}
Corn is one of the most important economic, social and cultural agricultural products in Paraguay, being the main ingredient of several typical foods. Due to the cross-pollination of this plant, it can be contaminated with transgenic maize pollen found in nearby fields. The general objective of this research was to evaluate the presence of transgenic sequences in corn grains marketed in the Departments of Itapúa, Alto Paraná and Canindeyú for the preparation of flour for human consumption. We studied 18 samples of corn kernels marketed for the preparation of flour from the Departments of Itapúa, Alto Paraná and Canindeyú. The DNA was extracted using the Trimethyl Ammonium Bromide (CTAB) protocol. For the detection of the transgenic sequences, the polymerase chain reaction (PCR) method was used. The bands were analyzed visually and using the ImageJ program. The results showed the presence of 5 positive samples for the P-35S-CaMv promoter and 5 samples for the T-nos terminator, none of them presented both sequences sought in the same construction; this indicates that 10 of 18 samples were contaminated with transgenic sequences. These findings show that transgenic products are available in Paraguayan local markets without consumers being aware of this situation.
\end{abstract}

Keywords: biotechnology; food safety; GMO; cross-pollination.

Practical Application: In the developing countries, the control of the quality and safety of food is practically non-existent. In Paraguay there is no legislation and control about the contamination of maize grains for human consumption with transgenic sequences. Since this cereal is highly susceptible to contamination for the pollination system it is a priority to initiate controls and establish bases for legislation on maximum acceptable limits in these products.

\section{Introduction}

Maize is one of the most important agricultural products worldwide, in terms of quantities produced, consumed and marketed (Wu, 2015). This cereal is important part in the diet of the population, consumed under many modalities, being the main ingredient of varied of typical preparations. In recent years, a sustained increase in corn production has been generated. Currently, new hybrids and transgenic varieties with better agronomic characteristics, resistance to different diseases, pests, and abiotic stresses (Alvarez et al., 2006; Nicolia et al., 2014; Cámara Paraguaya de Exportadores y Comercializadores de Cereales y Oleaginosas, 2016). As it is a cross-pollinated plant, there is a possibility that an accidental mixture between the genetically modified (GM) and non-GM material from nearby crops will occur (Devos et al., 2005). According to data from the International Service for the Acquisition of Agro-biotechnological Applications (Innes, 2006), there are 148 varieties of transgenic maize that include 404 events. In 1997 in Paraguay, biotechnological activities in the agricultural sector were regulated for the first time. For a GM event to be commercialized, it must be approved by the National Commission on Agricultural and Forestry
Biosafety (CONBIO) (Fernández Ríos et al., 2018). Actually, 19 corn events approved for environmental release are present (Servicio Nacional de Calidad y Sanidad Vegetal y de Semillas, 2017). Cauliflower mosaic virus $35 \mathrm{~S}$ promoter (P-35S-CaMV) primer and the Nopaline synthase terminator (T-NOSnos), present in the construction of $95 \%$ of the transgenic corn events (Zahradnik et al., 2014). Regarding the labeling of transgenic foods, it varies according to the regulations of the countries, can be obligatory, volunteer, even in certain countries a specific regulation has not yet been adopted (Wohlers, 2013). Consumers have questioned about food safety and current legislation about GMOs, which is why there is a growing need to assess their safety (Turkec et al., 2015).

Numerous analytical methods have been developed in DNA and proteins due to the challenge represented by the presence of GMOs in foods. (Kamle \& Ali, 2013). In Paraguay there is the possibility of cross-contamination due to the absence of control by regulatory agencies, therefore, it is important to use a simple and accessible technique such as the polymerase chain reaction (PCR) for the detection of the presence of transgenics in corn

${ }^{1}$ Facultad de Ciencias y Tecnología, Universidad Nacional de Itapúa, Encarnación, Paraguay

${ }^{2}$ Facultad Politécnica, Universidad Nacional de Asunción - UNA, Campus Universitario San Lorenzo, San Lorenzo, Paraguay

${ }^{3}$ Facultad de Ciencias Químicas, Universidad Nacional de Asunción - UNA, Campus Universitario San Lorenzo, San Lorenzo, Paraguay

${ }^{4}$ Centro Multidisciplinario de Investigaciones Tecnológicas - CEMIT, Dirección General de Investigación Científica y Tecnológica - DGICT, Universidad Nacional de Asunción

- UNA, Campus Universitario San Lorenzo, San Lorenzo, Paraguay

${ }^{5}$ Cámara Paraguaya de Exportadores y Comercializadores de Cereales y Oleaginosas - CAPECO, Asunción, Paraguay

${ }^{*}$ Corresponding author: aaarrua@gmail.com 
grains used for human consumption. Because the country has no regulation related to transgenic corn for human consumption, and labeling, the consumers have knowledge of what they are consuming and can make decisions regarding the acquisition of these products. Considering all these aspects, the present work we evaluated the presence of transgenic sequences in corn grains commercialized for human consumption in the Departments of Itapúa, Alto Paraná and Canindeyú.

\section{Materials and methods}

\subsection{Maize samples}

The grains were randomly collected from markets of the Departments of Itapúa (eight samples), Caazapá (five samples) and Canindeyú (five samples), with a total of 18 samples. As positive controls, two samples of corn grains from GM plants were used; information about construction was provided by suppliers. Commercial seeds of non-transgenic maize were also used as a negative control (Table 1).

\subsection{DNA extraction}

Seeds were sown in $700 \mathrm{~mL}$ pots to obtain leaf tissue for DNA extraction. The extraction of DNA from a pool of two leaves of maize two plants was carried out for 18 days following the CTAB protocol (Stacey \& Isaac, 1994). The concentration and purity of the extracted DNA were determined by absorbance readings at $260 \mathrm{~nm}$, in a microvolume spectrophotometer, DS-11 (DeNovix, Wilmington, DE, USA).

\subsection{Screening of GMOs}

For the screening of GMOs, the polymerase chain reaction (PCR) was performed, for the detection of the Cauliflower mosaic virus $35 \mathrm{~S}$ promoter (P-35S-CaMV) and the Nopaline

Table 1. Description of samples and origin of the samples.

\begin{tabular}{ccc}
\hline Name & Description & Origin \\
\hline i11 & Sample & Itapúa \\
i21 & Sample & Itapúa \\
i32 & Sample & Itapúa \\
i41 & Sample & Itapúa \\
i51 & Sample & Itapúa \\
i61 & Sample & Itapúa \\
i71 & Sample & Itapúa \\
i82 & Sample & Itapúa \\
a11 & Sample & Alto Paraná \\
a22 & Sample & Alto Paraná \\
a31 & Sample & Alto Paraná \\
a42 & Sample & Alto Paraná \\
a51 & Sample & Alto Paraná \\
c11 & Sample & Canindeyú \\
22 & Sample & Canindeyú \\
c31 & Sample & Canindeyú \\
c41 & Sample & Canindeyú \\
c51 & Sample & Canindeyú \\
SL1 & Itapúa \\
Pioneer 4785 & Itapúa \\
\hline
\end{tabular}

synthase terminator (T-NOS), present in the construction of 95\% of the transgenic corn events (Zahradnik et al., 2014) by using the primers of P-35S-F and P-35S-R that allow to amplify a fragment of $161 \mathrm{bp}$ and T-nos-F and T-nos-R, which amplify a fragment of $130 \mathrm{bp}$. The amplification was carried out with the use of the Dr. MAX DNA polymerase (Doctor protein INC, Korea) in a thermal cycler (DNA Engine Tetrad 2 Peltier Thermal Cycler, BIO-RAD). The thermocycling conditions were: a) initial denaturation: 5 minutes at $95^{\circ} \mathrm{C}$; b) 35 cycles of 30 seconds at $95^{\circ} \mathrm{C}$ for denaturation, 30 seconds at $60^{\circ} \mathrm{C}$ for annealing and 1 minute at $72{ }^{\circ} \mathrm{C}$ for elongation; and c) final elongation: 10 minutes at $72{ }^{\circ} \mathrm{C}$. The PCR product was purified using MultiScreen-PCR filter plate (Millipore Corp.,Burlington, MA, USA). PCR products were separated by electrophoresis on $1 \%$ agarose gel and stained with an intercalating fluorescent agent.

The data analysis was qualitative, by observing the bands of the electrophoresis gel of the amplification product of the regions studied. The frequency of maize contaminated with transgenics present in the different departments studied was analyzed.

\section{Results and discussion}

PCR analysis showed $27.78 \%$ contamination with transgenic material. High intensity bands were generated for the P-35S-CaMV with an observable amplicon of approximately $161 \mathrm{bp}$.

The findings of this study for the P-35S-CaMV promoter are similar with other authors who have reported their presence in corn samples commercially available in the markets of several countries. Rabiei et al. (2013) in Iran, studied 25 samples of corn grains and highly processed derived corn products, and found the presence of P-35S-CaMV in five samples, confirming the presence of GM material in $20 \%$ of the samples analyzed. Another study conducted on polenta corn flours in Uruguay by Fernández Campos et al. (2012), it was evidenced that $100 \%$ of the samples were positive for the P-35S-CaMV. For T-NOS, $27.78 \%$ of the samples was positive.

In total, 10 samples showed contamination with the transgenic sequences, corresponding to $55.56 \%$ of the total samples analyzed. Samples 8, 9, 10, 12 and 13 were positive for the P-35S-CaMV and samples 1, 2, 6, 16 and 18 were positive for T-NOS (Table 2).

None of the samples presented P-35S-CaMV and T-NOS in its construction, indicating that contamination occurred with those GM maize containing only one of these regulatory elements. Of the 19 GM maize approved for cultivation in Paraguay, four events contain P-35S-CaMV but not T-NOS and three contain T-NOS but not P-35S-CaVM (Supplementary Material). However, there is no information about which of the events are more cultivated in Paraguay. It should be noted that the samples that were negative, do not necessarily lack GM material, because we only evaluated the presence or absence of P-35S-CaVM and T-NOS for GMO tracking. All corn events that use different promoters and terminators in their construction were left out of the analysis. Currently, all events approved in Paraguay contain the P-35S-CaMV and T-NOS analyzed in this study, but the possibility that these maizes are contaminated with events that are approved in neighboring countries such as Argentina and Brazil cannot be ruled out. 
Table 2. General comparison of the two types of analysis for the interpretation of agarose gel electrophoresis.

\begin{tabular}{cccc}
\hline Sample & P-35S-CaMV & T-NOS & Result \\
\hline 1 & Negative & Positive & Positive \\
2 & Negative & Positive & Positive \\
3 & Negative & Negative & Negative \\
4 & Negative & Negative & Negative \\
5 & Negative & Negative & Negative \\
6 & Negative & Positive & Positive \\
7 & Negative & Negative & Negative \\
8 & Positive & Negative & Positive \\
9 & Positive & Negative & Positive \\
10 & Positive & Negative & Positive \\
11 & Negative & Negative & Negative \\
12 & Positive & Negative & Positive \\
13 & Positive & Negative & Positive \\
14 & Negative & Negative & Negative \\
15 & Negative & Negative & Negative \\
16 & Negative & Positive & Positive \\
17 & Negative & Negative & Negative \\
18 & Negative & Positive & Positive \\
\hline
\end{tabular}

${ }^{\star}$ Cauliflower mosaic virus 35 S promoter (P-35S-CaMV); ${ }^{* *}$ Nopaline synthase terminator (T-NOS).

For the Department of Itapúa, four of the eight samples analyzed presented nucleotide sequences of P-35S-CaMV or T-NOS corresponding to $50 \%$ of contamination. In Canindeyú Department, transgenic sequences were detected in four of the five samples studied, equivalent to $80 \%$ of contamination. Regarding the Department of Alto Paraná, two of the five samples analyzed contained GM sequences, corresponding to $40 \%$.

Similarly, in other countries, several authors have reported the presence of the same transgenic sequences used in this research for the detection of GMOs in corn. In Costa Rica, for the search of transgenic in processed foods whose main ingredient was based on corn and soybeans, Carvajal et al. (2017) analyzed 36 samples of solid foods, where the results revealed that $86 \%$ contained P-35S-CaMV and 72\% T-NOS, being that $29 \%$ of the samples were corn-based products. Also, in Portugal, Fernandes et al. (2014) analyzed the presence of P-35S-CaMV and T-NOS by PCR in 119 samples of corn grain, corn flour, among other products; the results showed that $30 \%$ were positive for the promoter and $10 \%$ for the terminator.

Mendoza et al. (2009) evaluated the presence of GMOs in processed food products derived from corn and soybeans (tortilla, tortilla chips and edible oils) using specific oligonucleotides of the $35 \mathrm{~S}$ promoter and T-NOS. The presence of the $35 \mathrm{~S}$ promoter indicated that they were contaminated with transgenic material. In Brazil, the presence of $35 \mathrm{~S}$ promoter, T-NOS and the Cry gene was evaluated in 12 GM maize samples of industrially processed products, dried grains and maize cobs marketed for fresh consumption. The results showed that only five of the corn flour samples had the correct specifications on their label indicating that it is a product based on transgenic corn. On the other hand, almost $90 \%$ of the ears were positive for at least one GM target, demonstrating the great use of genetically modified cultives to produce commercial ears for human consumption (Oliveira et al., 2016).

For the detection of contamination of the raw material for the production of goat cheese, Correa (2013) evaluated seven samples of cheese whose thickener was maize-based flour. The results showed that five samples were positive for the P-35S-CaMV, in the same way, the presence of three positive samples and two were also doubtful samples for the T-NOS In this way, it was evidenced that the samples of cheese were contaminated with corn flour of transgenic origin. Similarly, in Peru the presence of GMO was determined using the same promoter and terminator studied in this work, and in some cases, the detection of pat (phosphinothricin $\mathrm{N}$-acetyltransferase) gene and specific events such as MON810 and NK603, using real time PCR and immunological tests. The evaluated samples were collected from the cargo transports of the corn cultivars that supposed that they were not contaminated with transgenes. It was evidenced that P-35S-CaMV, T-NOS and the MON810 event were frequently found in these samples (Santa Maria et al., 2014). In similar investigations carried out on 74 processed foods from maize bases from the United States, China, Korea and Japan, it was observed that 18 of them contained one or more specific events of transgenic maize, among them the MON810, GA21 and NK603 (Kim et al., 2014).

As mentioned above, corn is a cross-pollinated crop that depends on the wind for the dispersion of its pollen, and there may be an accidental mixture between GM and non-GM material. The potential sources are the natural flow between neighboring fields, the use of impure seeds, the appearance of voluntary plants from seeds and / or vegetative parts of previous plants, among others (Devos et al., 2005), so the genetic structure of a variety is often not stable (Hernández Ramos et al., 2017). The accidental presence of GMO in Mexico, has been reported by Quist \& Chapela (2001) and Piñeyro Nelson et al. (2009) as a consequence of cross-pollination in native corn crops.

For the evaluation of the frequency of the presence of transgenes in the progenies of non GM crops that are close to GM crops, in Uruguay, Arleo (2015) used molecular techniques for the detection of GMO, where the results showed the existence of transgenic contamination in conventional crops near GMOs whose distance were up to $420 \mathrm{~m}$. It has been shown that corn pollen can travel distances greater than $800 \mathrm{~m}$. Depending on the climatic circumstances, it is important to develop methodologies that allow the detection of cross contamination in conjunction with policies of strict controls of buffer distances to ensure the coexistence of GM and non-GM crops (Devos et al., 2005).

One of the concerns that arise from the release of transgenic corn into the environment is the conservation of native / landraces and the distance needed to avoid cross-pollination (Vives Vallés, 2016). In 2010, in the United States, to mitigate the threat of resistance to insects, BT corn producers have imposed a strategy, which consists of a mixture of 5\% non-BT seed and 95\% BT seed, however, there is a concern for the compliance of these shelters due to the possibility of cross-pollination of maize hybrids that may induce the presence of BT proteins in the grains and that these negatively affect the survival, growth and development of the Refuge insects (Yang et al., 2014). In Paraguay, the recommended 
refuge depends on the area sown, it is recommended that it be $5 \%, 10 \%$ and $20 \%$ of non-GM seeds (Servicio Nacional de Calidad y Sanidad Vegetal y de Semillas, 2017); the degree of interpolinization between transgenic and non-transgenic maize is not known and, therefore, the degree of contamination with transgenic, this aspect is of interest for in situ conservation of local genetic resources.

Many years have passed since the introduction of GMOs in agriculture, but there are questions about the potential effects that this type of technology can generate on the genetic diversity of crops and on food security (Shao et al., 2015). Appropriate safety standards are needed to enable technological advancement and preserve public health and the environment. This is reflected in the ratification of more than 80 countries of the Cartagena Protocol on Biosafety, which regulates the trans boundary movement, transit, handling and use of living modified organisms (Pertry et al., 2016).

\section{Conclusions}

In Paraguay, transgenic sequences detection studies have not been reported. In this study, it was evidenced that 55.56\% of the samples analyzed were contaminated with transgenic sequences, indicating that corn contaminated with transgenes is commercialized, at least in the local markets of the three Departments included in this study, without any indication for consumers.

The sequences of the promoter and terminator used for the study were able to track the 19 events released to date in Paraguay, because all of them have these sequences in their construction.

\section{Acknowledgements}

To the National Council of Sciences and Technology (CONACYT) for the financing of the Master's Degree in Food Biotechnology. To the Faculty of Sciences and Technology of the National University of Itapúa and to the Multidisciplinary Center for Technological Research, General Directorate of Scientific and Technological Research, National University of Asunción (CEMIT-DGICT-UNA) for allowing the use of its laboratory.

\section{References}

Alvarez, M. L., Pinyerd, H. L., Crisantes, J. D., Rigano, M. M., Pinkhasov, J., Amanda, M., Walmsley, A. M., Masona, H. S., \& Cardineau, G. A. (2006). Plant-made subunit vaccine 158 J. S. DIAS AND R. ORTIZ against pneumonic and bubonic plague is orally immunogenic in mice. Vaccine, 24, 2477-2490.

Arleo, M. (2015). Detección y cuantificación de Organismos Genéticamente Modificados en cultivos de maíz y alimentos derivados, mediante análisis molecular (Tesis magíster). Universidad de la República, Montevideo, Uruguay.

Cámara Paraguaya de Exportadores y Comercializadores de Cereales y Oleaginosas - CAPECO. (2016). Área de siembra, producción y rendimiento. Asuncion: CAPECO. Retrieved from http://capeco. org.py/area-de-siembra-produccion-y-rendimiento/

Carvajal, P., Ureña, H., Umaña, J., Sancho, C., Solano, F., Arleo, M., Martínez, C., \& Umaña, R. (2017). Detección molecular de secuencias de ADN Transgénico en alimentos de consumo humano y animal en Costa Rica. Agronomia Costarricense, 41(1), 53-68. http://dx.doi. org/10.15517/rac.v41i1.29751.

Correa, J. (2013). Detección de leche bovina y maíz genéticamente modificado en Quesos de Cabra (Tesis licenciatura). Universidad de la República, Montevideo, Uruguay.

Devos, Y., Reheul, D., \& De Schrijver, A. (2005). The co-existence between transgenic and non-transgenic maize in the European Union: a focus on pollen flow and cross-fertilization. Environmental Biosafety Research, 4(1), 71-87. http://dx.doi.org/10.1051/ebr:2005013. PMid:16402663.

Fernandes, T. J. R., Amaral, J. S., Oliveira, M. B. P. P., \& Mafra, I. (2014). A survey on genetically modified maize in foods commercialised in Portugal. Food Control, 35(1), 338-344. http://dx.doi.org/10.1016/j. foodcont.2013.07.017.

Fernández Campos, M., Da Silva, A., \& Martínez Debat, C. (2012). Análisis de transgénesis mediante PCR de 20 harinas de maíz (polentas) que se encuentran a la venta en el mercado uruguayo. Revista Iberoamericana de Tecnología Postcosecha, 13(1), 92-104.

Fernández Ríos, D., Rubinstein, C., \& Vicién, C. (2018). Capacities for the risk assessment of GMOs: challenges to build sustainable systems. Frontiers in Bioengineering and Biotechnology, 6), 40. http://dx.doi. org/10.3389/fbioe.2018.00040. PMid:29675412.

Hernández Ramos, M. A., Rodriguez Larramendi, L. A., Guevara Hernández, F., Rosales-Esquianca, M. D. Á., Pinto-Ruiz, R., \& OrtizPérez, R. (2017). Caracterización molecular de maíces locales de la Biosfera La Sepultura, México. Agronomía Mesoamericana, 28(1), 69-83. http://dx.doi.org/10.15517/am.v28i1.21612.

Innes, N. (2006). Global Status of Commercialized Biotech/GM Crops: 2005. ISAAA Briefs No. 34. By C. James. Ithaca, NY, USA: ISAAA (2005), pp. 46, US\$50.00. Experimental Agriculture, 42(3), 372-372. https://doi.org/10.1017/S0014479706343797

Kamle, S., \& Ali, S. (2013). Genetically modified crops: detection strategies and biosafety issues. Gene, 522(2), 123-132. http://dx.doi. org/10.1016/j.gene.2013.03.107. PMid:23566850.

Kim, J. H., Zhang, D., \& Kim, H. Y. (2014). Detection of sixteen genetically modified maize events in processed foods using four event-specific pentaplex PCR systems. Food Control, 35(1), 345-353. http://dx.doi. org/10.1016/j.foodcont.2013.07.029.

Mendoza, A., Fernández, S., Cruz, M. A., Rodríguez-Perez, M. A., Resendez-Perez, D., \& Saldaña, H. A. B. (2009). Detection of genetically modified maize food products by the polymerase chain reaction. Food Science and Technology, 5(3), 175-181. http://dx.doi. org/10.1080/11358120609487689.

Nicolia, A., Manzo, A., Veronesi, F., \& Rosellini, D. (2014). An overview of the last 10 years of genetically engineered crop safety research. Critical Reviews in Biotechnology, 34(1), 77-88. http://dx.doi.org/1 0.3109/07388551.2013.823595. PMid:24041244.

Oliveira, C. A. M., Kommers, C. M., Lehmann, F. K. M., Fonseca, A. S. K., Ikuta, N., \& Lunge, V. R. (2016). Detection of genetically modified maize in processed products, dry grains, and corn ears intended for fresh consumption in South Brazil. Genetics and Molecular Research, 15(4). http://dx.doi.org/10.4238/gmr15048818. PMid:27813579.

Pertry, I., Sanou, E. I. R., Speelman, S., \& Ingelbrecht, I. (2016). The sucess story of Bt Cotton in Burkina Faso: a role model for sustainable cotton production in other cotton-growing countries? In: S. De Buck, I. Ingelbrecht, M. Heijde \& M. Van Montagu (Eds), Innovative Farming and Forestry across the Emerging World: The Role of Genetically Modified Crops and Trees (pp. 81-93). Belgium: International Industrial Biotechnology Network.

Piñeyro Nelson, A., Van Heerwaarden, J., Perales, H. R., Serratos-Hernández, J. A., Rangel, A., Hufford, M. B., Gepts, P., Garay-Arroyo, A., Rivera- 
Bustamante, R., \& Alvarez-Buylla, E. R. (2009). Transgenes in Mexican maize: molecular evidence and methodological considerations for GMO detection in landrace populations. Molecular Ecology, 18(4), 750-761. http://dx.doi.org/10.1111/j.1365-294X.2008.03993.x. PMid:19143938.

Quist, D., \& Chapela, I. H. (2001). Transgenic DNA introgressed into traditional maize landraces in Oaxaca, Mexico. Nature, 414(6863), 541-543. http://dx.doi.org/10.1038/35107068. PMid:11734853.

Rabiei, M., Mehdizadeh, M., Rastegar, H., Vahidi, H., \& Alebouyeh, M. (2013). Detection of genetically modified maize in processed foods sold commercially in Iran by qualitative PCR. Iranian Journal of Pharmaceutical Research, 12(1), 25-30. PMid:24250568.

Santa Maria, M. C., Lajo Morgan, G., \& Guardia, L. (2014). Adventitious presence of transgenic events in the maize supply chain in Peru: a case study. Food Control, 41(1), 96-101. http://dx.doi.org/10.1016/j. foodcont.2014.01.006.

Servicio Nacional de Calidad y Sanidad Vegetal y de Semillas - Senave. (2017). Listado de eventos de modificación genética liberados comercialmente en el país. Retrieved from http://www.senave.gov. py/docs/servicios/bioseguridad-agricola/2017/Listado de eventos de modificacion genetica liberados comercialmente en el pais.pdf

Shao, H., Wang, H., \& Tang, X. (2015). NAC transcription factors in plant multiple abiotic stress responses: Progress and prospects. Frontiers of Plant Science, 6, 1-8. http://dx.doi.org/10.3389/fpls.2015.00902.

Stacey, J., \& Isaac, P. (1994). Isolation of DNA from plants. In P. Isaac (Ed.), Methods in molecular biology: protocols for nucleic acid analysis by nonradioactive probes (pp. 9-15). Totowa: Humana Press.
Turkec, A., Kazan, H., Karacanli, B., \& Lucas, S. J. (2015). DNA extraction techniques compared for accurate detection of genetically modified organisms (GMOs) in maize food and feed products. Journal of Food Science and Technology, 52(8), 5164-5171. http://dx.doi.org/10.1007/ s13197-014-1547-8. PMid:26243938.

Vives Vallés, J. A. (2016). Derecho de cultivos transgénicos. El conflicto entre el Derecho español y el comunitario y el derecho a la libertad de empresa a la luz de la nueva normativa opt-out. (168 p.) Spain: Editorial Dykinson

Wohlers, A. E. (2013). Labeling of genetically modified food: closer to reality in the United States? Politics and the Life Sciences, 32(1), 73-84. http://dx.doi.org/10.2990/32_1_73. PMid:24047091.

Wu, F. (2015). Global impacts of aflatoxin in maize: trade and human health. World Mycotoxin Journal, 8(2), 137-142. http://dx.doi. org/10.3920/WMJ2014.1737.

Yang, F., Kerns, D. L., Head, G. P., Leonard, B. R., Levy, R., Niu, Y., \& Huang, F. (2014). A challenge for the seed mixture refuge strategy in Bt maize: Impact of cross-pollination on an ear-feeding pest, corn earworm. PLoS One, 9(11), 1-9. http://dx.doi.org/10.1371/ journal.pone.0112962.

Zahradnik, C., Kolm, C., Martzy, R., Mach, R. L., Krska, R., Farnleitner, A. H., \& Brunner, K. (2014). Detection of the $35 \mathrm{~S}$ promoter in transgenic maize via various isothermal amplification techniques: A practical approach. Analytical and Bioanalytical Chemistry, 406(27), 6835-6842. http://dx.doi.org/10.1007/s00216-014-7889-2. PMid:24880871. 


\section{Supplementary Material}

Supplementary material accompanies this paper.

Supplementary Table. Resumen de los dos tipos de análisis para la interpretación de la electroforesis del gel de agarosa

This material is available as part of the online article from http://www.scielo.br/cta 